\title{
Managing Pre-Construction and Construction Risks on Project Sites in Abuja-Nigeria
}

\author{
Jimoh, R.A. ${ }^{*}$, Sani, M.A. ${ }^{1}$, Adoza, A.I. ${ }^{1}$, and Yahaya, I. ${ }^{2}$
}

\begin{abstract}
Managing risks in construction projects has been acknowledged as a key direction process for the purposes of attaining the project goal in terms of time, cost, quality, safety, and environmental sustainability. Hence, the paper evaluated pre-construction and construction risks on active project sites in Abuja-Nigeria. This was achieved using survey method through the self-administration of 35 questionnaires to the professionals handling the 35 identified projects being undertaking at that time. Results showed that errors and omissions in design and improperly defined project scope had mean score values of 3.03 and 2.54, respectively, were the construction risks most experienced by the professionals during pre-construction. On the other hand, fluctuation in market prices and delays with mean score values of 3.14 and 2.74, respectively, were the construction risks experienced by the professionals during the construction phase of the projects. It is recommended that procurement methods such as construction management should be adopted and stakeholders should keep to their own side of the bargain to avoid unnecessary delays.
\end{abstract}

Keywords: Construction; process; pre-construction; risk; risk management; risk response.

\section{Introduction}

The idea of risk was known in economics around 1920s [1]. Risk has been viewed from different perspectives by many groups; based on point of view, attitudes, and know-how. Engineers, architects, and contractors look at risk from the technological viewpoint $[2,3]$. Project risk is described as an unsure incident or event that, when it happens, may bring about positive consequence on time, cost, and quality [4-6]. While Klemetti [7], defined risk as an unsure happening or state that has impact that contradicts project expectations when the project is completed. Chapman and Ward [8] further opined that risks are events that can bring deviation from what is designed or anticipated.

The success of every project depends on good management [7]. Enshassi, Mohammed, and AbuMosa [9] showed that the management of risks is a vital problem in the development and management of some occupation ventures. Hence, if a risk is not known it cannot be managed or transferred, but to do away with all risks in projects is not viable [1].

\footnotetext{
${ }^{1}$ Federal University of Technology, Minna, NIGERIA

2 Niger State College of Education, Minna, NIGERIA

* Corresponding author; e-mail: rosney@futminna.edu.ng
}

Note: Discussion is expected before June, $1^{\text {st }} 2016$, and will be published in the "Civil Engineering Dimension" volume 18, number 2, September 2016.

Received 30 December 2014; revised 26 September 2015; accepted 02 October 2015
Therefore, this necessitates official risk management development to control all forms of risks. The project achievement generally counts on bringing together all risks response schemes used to alleviate risks and a company's potential to control them [10]. Enshassi et al. [9] believed that management of risks is an essential problem in the setting up and management of any business undertaking. Hence, the primary perception of risk management is to handle risks effectively and efficiently [11]. Simu [12] opined that effective risk management is regarded as achieving the pre-determined targets for the project by applying the obtainable tools and techniques. In a related development, when looked at from the point of process effectiveness, implementing risk management is predicated on the skill of the project team [13].

\section{Literature Review}

Risk is inbuilt in all human activities, such as construction and the risk constituents concerned are diverse, risk falls into many classes and most at times the nature of risk depends on the scenario [14]. Klemetti [7] asserted that subcontracting is becoming more elaborate because lots of companies are concentrating only on their major businesses, which leads to additional difficulty on project networks and more project participants. However, research on how the project risk management should be related to the natural world is inadequate.

Risk management in construction is a difficult undertaking as the idea is subject to change throughout the execution of the project, nature of the construc- 
tion process and continuation of large number of parties that are concerned in the construction [15]. According to Uher [16], risk management is a tool that aims at discovering sources of risk and uncertainty, finding their impact, and growing suitable management responses in construction. Also Mills [17] opined that the reason for risk management in construction is to raise the prospect of project objectives. Patrick, Guomin, and Jia-Yuan [18] and Enshassi et al. [9] observed that managing risks in construction projects has been acknowledged as a key direction process for the purposes of attaining the project goal in terms of time, cost, quality, safety, and environmental sustainability. However, tremendous improvement can only be achieved in project management performance when greater attention is paid to the process of analysing project risks in order to meet up with project objectives [19].

To this end, Royer [20] stated that risk management must be of significant concern to project managers, as unmanaged or unmitigated risks are one of the key causes of project breakdown. Thus, Kaoje [21] opined that risk management in construction has to do with identifying risks, evaluating them and then developing strategies to deal with them. Chapman and Ward [8] argued that organizations which have laid down risk management ability as a process, gain vital advantage over contenders. Zayed, Amer, and Pan [22] asserted that risk management could be carried out through risk identification, risk assessment, and risk mitigation.

KarimiAzari et al. [1] stated that risk analysis can provide avenue for knowing the origins of project risk and enable management to develop directed corrective action. Rouse [23] concluded that risk analysis may either be quantitative or qualitative. In quantitative risk analysis, there is effort to find out the chances of many unfavourable actions and the probable level of the losses if certain event happens. While qualitative risk analysis, involves understanding the different threats, finding the degree of exposure and making counter measures when an attack occurs. Quantitative and qualitative risk analysis techniques as outlined by Hillson [5] and Thaheem [24] include: Quantitative-cash lock-up, internal rate of return, net present value, and payback period; Qualitative- brainstorming, checklist, interview, and priority table.

According to Hillson and Murray-Webster [25] and Simu [12], the effect of risk management should have a substantial relationship to the project objectives. But, according to Bresnen and Marshall [26], these objectives are not easy to apply owing to the problems involved in disaggregating them from the effects of other project administration processes.
Klemetti [7] suggested that, the potentials for development should also be considered. The level of risk and associated opportunity are usually high during the conception and design phases when the degree of uncertainty about the future is greatest. However, as the project progresses, risk parameters are reduced and unknowns become knowns [27]. Pre-construction services are defined as those services performed prior to the actual start of construction [28]. In the context of this definition, preconstruction risks are those risks that are planned for before the commencement of projects while construction risks are those risks that are encountered during the implementation (construction) of the project. It is in this regard that this paper evaluated pre-construction and construction risks on active project sites in Abuja-Nigeria with a view to minimising the negative consequence of risk threats. Active sites in this sense meant that questions were asked in relation to the projects being undertaking when the study was conducted.

The following objectives were pursued:

- To examine the risk encountered during preconstruction and construction stages

- To determine how the problems that arose as a result of this risks were resolved

- To determine contractor's perspective on the effect risk management process had on their construction projects when implemented.

\section{Research Methods}

Questionnaire survey was used for the study. Collis and Hussey [29] describe a survey as a positivistic methodology that draws a sample from a larger population in order to draw conclusions about the population. Non probability convenience sampling method was adopted; this is a sampling method according to Collins, Onwuegbuzie, and Jiao [30] that involves choosing from a sample that is not only accessible but the respondents are willing to take part in the study. The study was such that the respondents were asked questions based on the projects they were found handling during the selfadministration of the questionnaires. This was why the response was limited to 35 responses; invariably 35 projects were examined. Hence, the unit of analysis was the project each respondent was found undertaking. A unit of analysis according to Collis and Hussey [29] refers to the phenomenon under study, about which data is collected and analysed. The Likert scale was analysed using the cut-off points devised by Morenikeji [31] as follows:

- $\quad \geq 4.5$ = Extremely Significant (ES); Most Frequently Used (MFU); Strongly Agree (SA)

- 3.5-4.49 = Very significant (VS); Frequently Used (FU); Agree (A) 
- $\quad$ 2.50-3.49 = Significant (S); Unsure (U); Not Sure (NS)

- 1.5-2.49 = Slightly Significant (SS); Less Frequently Used (LF); Disagree (D)

- 1.0-1.49= Not Significant (NS); Least Frequently Used (LFU); Strongly Disagree (SD)

Table 1 indicates that $62.86 \%$ of the respondents had from 6 years and above in the construction industry. The respondents were made of architects (28.57\%), builders (25.71\%), structural engineers (11.43\%), quantity surveyors (17.14\%) and others that did not belong to those earlier mentioned (17.14\%). This is an indication that the responses of these professionals can be relied upon because of their years of experience and their professional qualification.

Table 2 shows th.at more than half of the respondents are involved in residential type of construction. Table 3 shows th.at $62.86 \%$ of the respon.dents used qualitative analysis method which may include interview and brainstorming while the remaining $37.14 \%$ of the respondents used quantitative analysis method which may include scenario and sensitivity analyses. This means that majority of the respondents use qualitative analysis method while analysing preconstruction and construction risks. This may be due to the seemingly less mathematical expressions involved in this method when compared with the quantitative approach.

From Table 4, errors and omissions in design under design risk has the highest mean score (MS) of 3.03, followed by interaction of design with method of construction having MS of 1.49.

Table 1. Category of Respon.dents by Ye.ars of Ex.perience

\begin{tabular}{lcc}
\hline Years of experience & Frequency & Percentage \\
\hline $1-5$ & 13 & 37.14 \\
$6-10$ & 13 & 37.14 \\
$11-15$ & 6 & 17.14 \\
$16-20$ & 1 & 2.86 \\
Above 20 & 2 & 5.71 \\
\hline Total & 35 & 100.0 \\
\hline
\end{tabular}

Table 2. Nature of Project

\begin{tabular}{lcc}
\hline \multicolumn{1}{c}{ Type of Project } & Frequency & Percentage \\
\hline Residential & 19 & 54.30 \\
Commercial & 8 & 22.86 \\
Industrial & 4 & 11.43 \\
Public utility & 4 & 11.43 \\
\hline Total & 35 & 100.0 \\
\hline
\end{tabular}

Table 3. Method Applied During Risk Analysis

\begin{tabular}{lcc}
\hline \multicolumn{1}{c}{ Method } & Frequency & Percentage \\
\hline Qualitative & 22 & 62.86 \\
Quantitative & 13 & 37.14 \\
\hline Total & 35 & 100.0 \\
\hline
\end{tabular}

Under estimating risk, improperly defined project scope is ranked highest with MS of 2.54, then followed by competitive tendering risk under which inappropriate tender method or contract document form ranked highest with MS of 1.94. Under tender evaluation risk, incorrect labour or materials costs, or miscalculations in any figures given is ranked highest with MS of 2.17. From the analysis errors and omissions in design is ranked highest which means it is the risk that most respondents encountered during pre-construction stage. A benefit of adopting construction management as a procurement system is the early involvement of the contractor in the planning stages of a project as this will make the client to be able to utilise the contractor construction expertise in all aspects of the design and planning [28].

From Table 5, fluctuation in market prices under financial risk has the highest MS of 3.14, while under political risk, religious and cultural conflicts ranked highest with MS of 2.40, then followed by physical risk under which accidents on construction sites ranked highest with MS of 1.91, while under contractual risk, delays ranked highest with MS of 2.71 , followed by claims and disputes with MS of 1.74. Under logistic risk, availability to suitable labour and materials ranked highest with MS of 1.91. Under legal risk, coping with local laws ranked highest with MS of 1.89, and finally under environmental risk, reclaimed land ranked highest with MS of 1.57 among others. From the analysis, financial risk is ranked highest based on overall ranking which shows it is the most encountered risk during construction by the respondents.

From Table 6, risk avoidance ranked highest with MS of 4.34 as the risk response system used by the respondents, risk mitigation has MS value of 3.57 , risk transfer has MS value of 3.54, and finally, risk acceptance has MS value of 3.11. From the analysis, all the risk response systems are frequently used by the respondents when benchmarked against Morenikeji [31] cut-off points.

From Table 7, 'The outcome after the application was favourable and prevented excess loss' ranked highest with MS of 4.51; 'Application of risk management process ensured that the project had a better chance of yielding profit rather than loss' has MS value of 4.29. Some of the risks could not be avoided and hence lead to losses though were insignificant has MS value of 3.63 and lastly, 'Some of the risks were transferred' has MS value of 3.46. From the analysis, the respondents could be deemed to agree to the possible outcome after applying risk management process to their construction projects based on the cut-off points devised. 
Table 4. Ranking of the Risk Encountered During Pre-construction

\begin{tabular}{|c|c|c|c|c|c|c|c|c|c|c|c|}
\hline $\mathrm{S} / \mathrm{N}$ & Preconstruction risks & $\begin{array}{c}\mathrm{ES} \\
5 \\
\end{array}$ & $\begin{array}{c}\mathrm{VS} \\
4 \\
\end{array}$ & $\begin{array}{l}\mathrm{S} \\
3 \\
\end{array}$ & $\begin{array}{c}\mathrm{SS} \\
2 \\
\end{array}$ & $\begin{array}{c}\mathrm{NS} \\
1 \\
\end{array}$ & NR & TS & MS & RNK & RMK \\
\hline 1.0 & Design risk & & & & & & & & & & \\
\hline 1.1 & Errors and omissions in design & 60 & 28 & 9 & 6 & 3 & 35 & 106 & 3.03 & $1^{\text {st }}$ & $\mathrm{S}$ \\
\hline 1.2 & $\begin{array}{l}\text { Incorporation of new construction } \\
\text { techniques }\end{array}$ & 5 & 4 & 15 & 10 & 2 & 35 & 36 & 1.03 & $3^{\text {rd }}$ & NS \\
\hline 1.3 & $\begin{array}{l}\text { Interaction of design with method of } \\
\text { construction }\end{array}$ & 10 & 20 & 15 & 4 & 3 & 35 & 52 & 1.49 & $2^{\text {nd }}$ & NS \\
\hline & Mean & & & & & & & 65 & 1.85 & & \\
\hline & Std Deviation & & & & & & & 29.92 & 0.85 & & \\
\hline 2.0 & Estimating risk & & & & & & & & & & \\
\hline 2.1 & Improperly defined project scope & 45 & 16 & 24 & 2 & 2 & 35 & 89 & 2.54 & $1^{\text {st }}$ & $\mathrm{S}$ \\
\hline 2.2 & Overly optimistic schedule & 0 & 12 & 18 & 4 & 2 & 35 & 36 & 1.03 & $3^{\text {rd }}$ & NS \\
\hline 2.3 & Inadequate information details & 40 & 24 & 9 & 4 & 2 & 35 & 79 & 2.26 & $2^{\text {nd }}$ & SS \\
\hline & Mean & & & & & & & 68 & 1.94 & & \\
\hline & Std Deviation & & & & & & & 23.0 & 0.66 & & \\
\hline 3.0 & Competitive tendering risk & & & & & & & & & & \\
\hline 3.1 & $\begin{array}{l}\text { Inappropriate tender method or contract } \\
\text { document form. }\end{array}$ & 25 & 32 & 3 & 4 & 4 & 35 & 68 & 1.94 & $1^{\text {st }}$ & SS \\
\hline 3.2 & Specify the wrong requirements & 45 & 8 & 3 & 4 & 4 & 35 & 54 & 1.83 & $2^{\text {nd }}$ & SS \\
\hline 3.3 & $\begin{array}{l}\text { Selection of inappropriate service } \\
\text { provider }\end{array}$ & 20 & 16 & 9 & 8 & 4 & 35 & 67 & 1.63 & $3^{\text {rd }}$ & SS \\
\hline & Mean & & & & & & & 63 & 1.80 & & \\
\hline & Std Deviation & & & & & & & 6.38 & 0.13 & & \\
\hline 4.0 & Tender evaluation risk & & & & & & & & & & \\
\hline 4.1 & $\begin{array}{l}\text { Incorrect labour or materials costs, or } \\
\text { miscalculations in any figures given }\end{array}$ & 40 & 24 & 9 & 2 & 1 & 35 & 76 & 2.17 & 1st & SS \\
\hline 4.2 & Inadequate or inconsistent evaluation & 15 & 24 & 12 & 6 & 2 & 35 & 59 & 1.69 & $2^{\text {nd }}$ & NS \\
\hline 4.3 & $\begin{array}{l}\text { Exposure through clauses that work } \\
\text { against the company, such as clauses } \\
\text { that hold the contractor responsible } \\
\text { for circumstances outside their } \\
\text { control. }\end{array}$ & 20 & 4 & 9 & 2 & 5 & 35 & 40 & 1.14 & $3^{\text {rd }}$ & NS \\
\hline & Mean & & & & & & & 58 & 1.67 & & \\
\hline & Std Deviation & & & & & & & 14.70 & 0.41 & & \\
\hline
\end{tabular}

ES-Extremely significant; VS-Very significant; S-Significant; SS-Slightly significant; NS-Not significant; NR-Number of responses; TS-Total score; MS-Mean score; RNK-Rank; RMK-Remark

Respondents' comments on how the risks encountered during pre-construction were resolved

- Contingency (sum) is allotted to such unforeseen risk, such that the burden of the risk will not totally deflect the profit margin of the project.

- The problem of errors and omissions in design were resolved using knowledge of similar work done as well as knowledge of the relevant laws guiding the area. Also, using direct labour system helped in reducing cost and misuse of materials.

- By making sure there is an understanding between the client and us. Discussing about liable risks, and making sure that all the stakeholders are involved during the planning stage.

- Further consultations and making new and applicable decisions.

Respondents' comments on how the risks encountered during construction were resolved

- Proper site management of the site during the construction stage was adopted. Also, a portion of the risk which is transferable was transferred to other parties in the project.

- Insurance was provided to handle life and other physical risks as regards personnel on site. Provision and approval were made to manage material price fluctuation with reference to the distance from the point of purchase.

- A contingency sum is set aside for fluctuation in market prices. The client is always advised to clearly stick with the agreed terms of cash in-flow in order to reduce the risk of delays.

- The problem of financial risks was solved by the terms and conditions in the contractual documents signed by both parties. The problems of accidents was solved by ensuring the third party insurance automatically takes care of the victims. Logistical issues were also taken care of by suppliers because they are responsible for materials not yet on site by the agreement 
Table 5. Ranking of the Risk Encountered During Construction

\begin{tabular}{|c|c|c|c|c|c|c|c|c|c|c|c|}
\hline $\mathrm{S} / \mathrm{N}$ & Construction risks & $\begin{array}{c}\mathrm{ES} \\
5\end{array}$ & $\begin{array}{c}\mathrm{VS} \\
4\end{array}$ & $\begin{array}{l}\mathrm{S} \\
3\end{array}$ & $\begin{array}{c}\mathrm{SS} \\
2\end{array}$ & $\begin{array}{c}\mathrm{NS} \\
1\end{array}$ & NR & TS & MS & RNK & RMK \\
\hline 1.0 & Financial risk & & & & & & & & & & \\
\hline 1.1 & fluctuation in market prices & 70 & 24 & 12 & 4 & 0 & 35 & 110 & 3.14 & $1^{\text {st }}$ & $\mathrm{S}$ \\
\hline 1.2 & Inadequate cash flow & 35 & 32 & 15 & 4 & 3 & 35 & 89 & 2.54 & $2^{\text {nd }}$ & $\mathrm{S}$ \\
\hline \multirow[t]{3}{*}{1.3} & Inflation and taxation & 10 & 16 & 3 & 6 & 2 & 35 & 37 & 1.06 & $3^{\text {rd }}$ & NS \\
\hline & Mean & & & & & & & 79 & 2.25 & & \\
\hline & Std Deviation & & & & & & & 30.68 & 0.87 & & \\
\hline 2.0 & Political risk & & & & & & & & & & \\
\hline 2.1 & Religious and cultural conflicts & 40 & 20 & 12 & 8 & 4 & 35 & 84 & 2.40 & $1^{\text {st }}$ & SS \\
\hline 2.2 & Changes in laws or decrees & 15 & 8 & 18 & 4 & 4 & 35 & 49 & 1.40 & $2^{\text {nd }}$ & NS \\
\hline \multirow[t]{3}{*}{2.3} & Revolution & 5 & 4 & 12 & 6 & 5 & 35 & 32 & 0.91 & $3^{\text {rd }}$ & NS \\
\hline & Mean & & & & & & & 55 & 1.57 & & \\
\hline & Std Deviation & & & & & & & 21.65 & 0.63 & & \\
\hline 3.0 & Physical risk & & & & & & & & & & \\
\hline 3.1 & Accidents on construction sites & 30 & 20 & 9 & 4 & 4 & 35 & 67 & 1.91 & $1^{\text {st }}$ & SS \\
\hline 3.2 & Flood & 10 & 24 & 3 & 2 & 3 & 35 & 42 & 1.20 & $3^{\text {rd }}$ & NS \\
\hline \multirow[t]{3}{*}{3.3} & Site difficulty & 25 & 8 & 21 & 6 & 3 & 35 & 63 & 1.80 & 2nd & SS \\
\hline & Mean & & & & & & & 57 & 1.64 & & \\
\hline & Std Deviation & & & & & & & 10.96 & 0.30 & & \\
\hline 4.0 & Contractual risk & & & & & & & & & & \\
\hline 4.1 & Claims and disputes & 20 & 24 & 12 & 4 & 1 & 35 & 61 & 1.74 & $2^{\text {nd }}$ & $\mathrm{SS}$ \\
\hline 4.2 & Disruption of work & 10 & 12 & 12 & 6 & 2 & 35 & 42 & 1.20 & $3^{\text {rd }}$ & NS \\
\hline \multirow[t]{3}{*}{4.3} & Delays & 40 & 24 & 27 & 4 & 1 & 35 & 96 & 2.74 & $1^{\mathrm{st}}$ & $\mathrm{S}$ \\
\hline & Mean & & & & & & & 66 & 1.89 & & \\
\hline & Std Deviation & & & & & & & 22.37 & 0.64 & & \\
\hline 5.0 & Logistics risk & & & & & & & & & & \\
\hline 5.1 & $\begin{array}{l}\text { Damage to materials and } \\
\text { equipment during } \\
\text { transportation }\end{array}$ & 25 & 16 & 6 & 6 & 1 & 35 & 54 & 1.54 & $2^{\text {nd }}$ & SS \\
\hline 5.2 & $\begin{array}{l}\text { Availability of suitable labour } \\
\text { and materials }\end{array}$ & 15 & 24 & 21 & 4 & 3 & 35 & 67 & 1.91 & $1^{\text {st }}$ & SS \\
\hline \multirow[t]{3}{*}{5.3} & $\begin{array}{l}\text { access to spare parts for } \\
\text { equipment }\end{array}$ & 15 & 12 & 6 & 8 & 2 & 35 & 43 & 1.23 & $3^{\text {rd }}$ & NS \\
\hline & Mean & & & & & & & 55 & 1.56 & & \\
\hline & Std Deviation & & & & & & & 9.81 & 0.28 & & \\
\hline 6.0 & Legal risk & & & & & & & & & & \\
\hline 6.1 & Liability for acts of others & 25 & 8 & 9 & 6 & 4 & 35 & 52 & 1.49 & $2^{\text {nd }}$ & NS \\
\hline 6.2 & Direct liabilities & 4 & 12 & 12 & 6 & 2 & 35 & 37 & 1.06 & $3^{\text {rd }}$ & NS \\
\hline \multirow[t]{3}{*}{6.3} & Coping with local laws & 20 & 24 & 18 & 2 & 2 & 35 & 66 & 1.89 & $1^{\text {st }}$ & $\mathrm{SS}$ \\
\hline & Mean & & & & & & & 52 & 1.48 & & \\
\hline & Std Deviation & & & & & & & 11.84 & 0.35 & & \\
\hline 7.0 & Environmental risk & & & & & & & & & & \\
\hline 7.1 & Reclaimed land & 20 & 12 & 18 & 4 & 1 & 35 & 55 & 1.57 & $1^{\text {st }}$ & SS \\
\hline 7.2 & Contaminated site & 25 & 0 & 9 & 2 & 4 & 35 & 40 & 1.14 & $3^{\text {rd }}$ & NS \\
\hline \multirow[t]{3}{*}{7.3} & Ecologically damaged sites & 20 & 8 & 9 & 2 & 6 & 35 & 45 & 1.29 & $2^{\text {nd }}$ & NS \\
\hline & Mean & & & & & & & 47 & 1.33 & & \\
\hline & Std Deviation & & & & & & & 6.24 & 0.17 & & \\
\hline
\end{tabular}

ES-Extremely significant; VS-Very significant; S-Significant; SS-Slightly significant; NS-Not significant; NR-Number of responses; TS-Total score; MS-Mean score; RNK-Rank; RMK-Remark

Table 6. Risk Response System Used by Respondent

\begin{tabular}{llcccccccccc}
\hline S/N & Systems & MFU 5 & FU 4 & U & LF & LFU & NR & TS & MS & RNK & RMK \\
& & & & 3 & 2 & 1 & & & & & \\
\hline 1 & Risk mitigation & 50 & 40 & 24 & 10 & 1 & 35 & 125 & 3.57 & $2^{\text {nd }}$ & FU \\
2 & Risk avoidance & 90 & 40 & 12 & 8 & 0 & 35 & 152 & 4.34 & $1^{\text {st }}$ & FU \\
3 & Risk transfer & 65 & 32 & 15 & 6 & 6 & 35 & 125 & 3.54 & $3^{\text {rd }}$ & FU \\
4 & Risk acceptance & 25 & 44 & 27 & 8 & 5 & 35 & 109 & 3.11 & $4^{\text {th }}$ & U \\
\hline Mean & & & & & & & 128 & 3.64 & & \\
\hline & Std Deviation & & & & & & 15.45 & 0.29 & & \\
\hline
\end{tabular}

MFU-Most frequently used; FU-Frequently used; U-Unsure; LF-Less frequently used; LFU-Least frequently used; NRNumber of responses; TS-Total score; MS-Mean score; RNK-Rank; RMK-Remark 
Table 7. Outcome after Applying Risk Management Process

\begin{tabular}{|c|c|c|c|c|c|c|c|c|c|c|c|}
\hline $\mathrm{S} / \mathrm{N}$ & Possible outcome & $\begin{array}{c}\mathrm{SA} \\
5\end{array}$ & $\begin{array}{c}\mathrm{A} \\
4\end{array}$ & $\begin{array}{c}\mathrm{NS} \\
3\end{array}$ & $\begin{array}{l}\mathrm{D} \\
2\end{array}$ & $\begin{array}{c}\text { SD } \\
1\end{array}$ & NR & TS & MS & RNK & RMK \\
\hline 1 & $\begin{array}{l}\text { The outcome after the } \\
\text { application was favourable } \\
\text { and prevented excess loss }\end{array}$ & 100 & 56 & 0 & 2 & 0 & 35 & 158 & 4.51 & $1 \mathrm{st}$ & SA \\
\hline 2 & $\begin{array}{l}\text { Some of the risks could not be } \\
\text { avoided and hence lead to } \\
\text { losses though were } \\
\text { insignificant }\end{array}$ & 50 & 52 & 15 & 6 & 4 & 35 & 127 & 3.63 & $3^{\text {rd }}$ & A \\
\hline 3 & $\begin{array}{l}\text { Some of the risks were } \\
\text { transferred }\end{array}$ & 35 & 52 & 21 & 10 & 3 & 35 & 121 & 3.46 & $4^{\text {th }}$ & $\mathrm{A}$ \\
\hline 4 & $\begin{array}{l}\text { Application of risk } \\
\text { management process } \\
\text { ensured that the project } \\
\text { had a better chance of } \\
\text { yielding profit rather than } \\
\text { loss }\end{array}$ & 110 & 32 & 6 & 0 & 2 & 35 & 150 & 4.29 & $2^{\text {nd }}$ & $\mathrm{A}$ \\
\hline & Mean & & & & & & & 139 & 3.97 & & \\
\hline & Std Deviation & & & & & & & 13.13 & 0.45 & & \\
\hline
\end{tabular}

SA-Strongly Agree; A-Agree; NU- Not sure; D-Disagree; SD-Strongly disagree; NR-Number of responses; TS-Total score; MS-Mean score; RNK-Rank; RMK-Remark

\section{Conclusion}

The paper evaluated pre-construction and construction risks on active project sites in Abuja-Nigeria. Thirty-five projects were examined; there were 23 residential projects representing 54.8\%, 9 commercial projects representing $21.43 \%$ while industrial and public utility bring up the rear consisting of 5 projects each representing $11.9 \%$. During the preconstruction phase, it was discovered that the construction risks experienced the most by the respondents under design, estimating, tendering, tender evaluations risks were errors and omissions in design (3.03), inadequate information details (2.26), specify the wrong requirements (1.83) and inadequate or inconsistent evaluation (1.69) respectively. In a related development, during the construction phase of the projects, it was discovered that the highest risks experienced by the respondents under financial, political, physical, contractual, logistic, and environmental risks were inadequate cash flow (2.54), religious and cultural conflicts (2.40), site difficulty (1.80), delays (2.70), availability of labour and materials (1.91), and reclaimed land (1.54) respectively. The respondents alluded to the fact that after adopting the risk management process, the outcome was favourable and it ensured that the projects had better yielding profits rather than loss. Based on these results, it could be inferred that it was not likely that buildability and maintainability analysis was carried out in any of the projects hence the errors and omissions in design and the incomplete information found in the estimating. There was also the possibility of not paying the contractors on time by the clients hence the delays recorded in the projects. The following are however suggested:
- Buildability and maintainability report should be made mandatory in all projects as this will limit many of the pre-construction risks experienced.

- Using procurement method such as construction management, errors and omissions in design, inadequate information details, and specifying the wrong requirements will be minimised since the contractor will be brought early enough into the project unlike the traditional procurement system.

- All the stakeholders should ensure that they keep to their own side of the bargain in order to reduce delays.

\section{References}

1. KarimiAzari, A., Mousavi, N,S., Farid-Mousavi, S.F., and Hosseini, S., Risk Assessment Model Selection in Construction Industry, Journal of Expert Systems with Applications, 38, 2011, pp. 9105-9111.

2. Baloi, D. and Price, A.D.F., Modelling Global Risk Factors affecting Construction Cost Performance, International Journal of Project Management, 21, 2003, pp. 261-269.

3. Hillson, D., Extending the Risk Process to Manage Opportunities, International Journal of Project Management, 20(3), 2002, pp. 235-240.

4. Olsson, R., In Search of Opportunity Management: Is the Risk Management Process Enough, International Journal of Project Management, 25, 2007, pp. 745-752.

5. Hillson, D., Effective Opportunity Management for Projects - Exploiting Positive Risk, Marcel Dekker, New York, 2004. 
6. Perminova, O., Gustafsson, M., and Wikstrom, K., Defining Uncertainty in Projects - A New Perspective, International Journal of Project Management, 26, 2008, pp. 73-79.

7. Klemetti, A., Risk Management in Construction Project Networks, Laboratory of Industrial Management, Helsinki University of Technology, 2006.

8. Chapman, C.B. and Ward, S.C., Project Risk Management: Processes, Techniques and Insights, $2^{\text {nd }}$ edition, John Wiley and Sons, Chichester, 2003.

9. Enshassi, A., Mohamed, S., and Abu-Mosa, J., Risk Management in Building Projects in Palestine: Contractors' Perspective, Emirates Journal for Engineering Research, 13(1), 2008, pp. 29-44.

10. Dikmen, I., Birgonul, M.T., and Han, S., Using Fuzzy Risk Assessment to Rate Cost Overrun Risk in International Construction Projects, International Journal of Project Management, 25, 2007, pp. 494-505.

11. Thevendran, V. and Mawdesley, M.J., Perception of Human Risk Factors in Construction Projects: An Exploratory Study, International Journal of Project Management, 22, 2004, pp. 131-137.

12. Simu, K., The Construction Site Manager's Impact on Risk Management Performance, Doctoral Thesis, Department of Civil, Mining and Environmental Engineering, Luleå University of Technology, 2009.

13. Pangeran, M.H., Pribadi, K.S., Wirahadikusumah, R.D., and Notodarmojo, S., Assessing Risk Management Capability of Public Sector Organisations Related to PPP Scheme Development for Water Supply in Indonesia, Civil Engineering Dimension, 14(1), 2012, pp. 26-35.

14. Adelusi, A.K., Assessment of Risk and Risk Management Stages in Nigerian Construction Industry, Unpublished B. Tech Project, Department of Quantity Surveying, Federal University of Technology, Akure-Nigeria, 2009.

15. Dikmen, I., Birgonul, M.T., Anac, C., Tah, J.H. M., and Aouad, G., Learning from Risks: A Tool for Post-Project Risk Assessment, Automation in Construction, 18, 2008, pp. 42-50.

16. Uher, T., Programming and Scheduling Techniques, UNSW Press, Sydney, 2003

17. Mills, A., A Systematic Approach to Risk Management for Construction, Structural Survey, 19(5), 2001, pp. 245-252.

18. Patrick, X.W.Z., Guomin Z., and Jia-Yuan, W., Identifying Key Risks in Construction Projects: Life Cycle and Stakeholder Perspectives, 2006, retrieved from http://prres. net/Papers/Zou_risks_ in_construction_project.pdf.
19. Andi, Appropriate Allocation of Contingency using Risk Analysis Methodology, Civil Engineering Dimension, 6(1), 2004, pp. 40-48.

20. Royer, P.S., Risk Management: The Undiscovered Dimension of Project Management, Project Management Journal, 31(1), 2000, pp. 613.

21. Kaoje, B.B., Risk Management in Construction using Web-based Collaboration to Manage Project Risk, Proceedings of the 40th Annual General Meeting/Conference of the Nigerian Institute of Building: Risk Management in Construction, August, 2010.

22. Zayed, T., Amer, M., and Pan, J., Assessing Risk and Uncertainty Inherent in Chinese Highway Projects using AHP, International Journal of Project Management, 26, 2008, pp. 408-419.

23. Rouse, M., Essential Guide to Business Continuity and Disaster Recovery Plans, Risk Analysis, CW Europe, Australia, 2010.

24. Thaheem, J., A Review of Quantitative Analysis Techniques for Construction Project Risk Management, Creative Construction Conference, Budapest, Hungary, 2012.

25. Hillson, D. and Murray-Webster, R., Understanding and Managing Risk Attitude, Gower Publishing Limited, Hampshire, 2005.

26. Bresnen, M. and Marshall, N., Understanding the Diffusion and Application of New Management Ideas in Construction, Engineering, Construction and Architectural Management, 8(5/6), 2001, pp. 335-345.

27. Burke, R., Project Management Techniques, Burke Publishing, South Africa, 2010.

28. The Associated General Contractors of America and The Council of Educational Facility Planners International, Construction Manager at Risk, 2002, retrieved from http://agchouston.org/ files/2027_Construction_Manager_at_Risk_Refer ence_Document.pdf.

29. Collis, J. and Hussey, R., Business Research: A Practical Guide for Undergraduate and Postgraduate Students, 2nd edition, Palgrave Macmillan, New York, 2003.

30. Collins, K.M.T., Onwuegbuzie, A.J., and Jiao, Q.G., A Mixed Methods Investigation of Mixed Methods Sampling Designs in Social and Health Science Research, Journal of Mixed Methods Research, 1(3), 2007, pp. 267-294.

31. Morenikeji, W., Research and Analytical Methods (for Social Scientists, Planners and Environmentalists), Jos University Press Limited, Jos, 2006. 